\title{
PERFORMANCE IMPROVEMENT OF BLUD PUSKESMAS EMPLOYEES BASED ON THE RELIANCE ON MULTIPLE PERFORMANCE MEASURE THROUGH LEVERS OF CONTROL
}

\author{
Efrizal Syofyan \\ efrizal_syofyan@fe.unp.ac.id \\ Universitas Negeri Padang \\ Riski Hernando \\ Universitas Jambi
}

\begin{abstract}
ABSTRAK
Penelitian ini menguji pengaruh ketergantungan berbagai ukuran kinerja (finansial dan non-keuangan) terhadap kinerja pegawai Badan Layanan Umum Daerah (BLUD) Pusat Kesehatan Masyarakat (Puskesmas) atau Badan Layanan Umum Daerah Puskesmas Tanjung Jabung Barat dan Kabupaten Batanghari. Studi ini juga menganalisis dampak hubungan yang dimediasi oleh Levers of Control (sistem kontrol diagnostik dan sistem kontrol interaktif). Populasi dalam penelitian ini adalah pegawai BLUD Puskesmas Tanjung Jabung Barat dan BLUD Puskesmas Batanghari yang diambil sebagai sampel sebanyak 81 responden. Penelitian ini menggunakan structural equation modelling (SEM-PLS) dengan software WarpPLS versi 7.0. Studi ini menunjukkan bahwa Levers of Control memediasi hubungan antara ketergantungan pada beberapa ukuran kinerja pada kinerja. Namun, studi ini gagal menunjukkan bahwa kinerja BLUD Puskesmas dipengaruhi oleh ketergantungan pada berbagai ukuran kinerja. Studi ini memberikan kontribusi penting bagi BLUD Puskesmas bukan hanya di Kabupaten Tanjung Jabung Barat dan Batanghari akan tetapi juga BLUD Puskesmas di Indonesia berupa penggunaan levers of control sebagai variabel mediasi hubungan antara ketergantungan pada beberapa ukuran kinerja pada kinerja pegawai BLUD Puskesmas.
\end{abstract}

Kata kunci: kinerja pegawai, levers of control, reliance multiple performance measures, blud puskesmas

\section{ABSTRACT}

This study examines the effect of reliance on multiple performance measures (financial and non-financial) on the employee performance of the Badan Layanan Umum Daerah (BLUD) Pusat Kesehatan Masyarakat (Puskesmas) or Regional Public Service Agency of Community Health Centre in Tanjung Jabung Barat and Batanghari districts. This study also analyzes the impact of this relationship mediated by the levers of control (diagnostic control system and interactive control system). The population of this study were the employees of the BLUD Puskesmas Tanjung Jabung Barat and BLUD Puskesmas Batanghari, from which 81 respondents were recruited as the sample. This study using structural equation modelling - partial least square (SEM-PLS) with WarpPLS software version 7.0. This study shows that the levers of control mediate the relationship between reliance on multiple performance measures on performance. However, this study fails to show that the performance of BLUD Puskesmas is influenced by the reliance on multiple performance measures. This studi give crucial contributes for BLUD Puskesmas not only in Tanjung Jabung Barat and Batanghari district but also for BLUD Puskesmas in Indonesia as mediates relationship between reliance on multiple performance measures on performance of BLUD Puskesmas employees

Key words: performance of employees, levers of control, reliance multiple performance measures, blud puskesmas

\section{INTRODUCTION}

The success of a company reflects the performance of its superiors and subor- dinates. The measures used to evaluate the performance of a company's superiors and subordinates so far have only relied on 
financial and non-financial performance (Lau and Roopnarain, 2014; Speklé and Verbeeten, 2014; Lau, 2015; Shahwan, 2015; Ghozali and Sulityani, 2016; Galant and Cadez, 2017; Susiana et al., 2018). However, it is still appropriate to implement financial and non-financial performance measurement systems. However, it still shows mixed results (Hartmann et al., 2010). Previous research findings proved that financial and non-financial performance measurement systems can be combined with levers of control to increase the performance of superiors and subordinates in a company (Marginson et al., 2014; Afrizal et al., 2020; Hernando, 2020). The combination of performance measurement with levers of control is expected to avoid a decline in company performance caused by a decrease in the performance of both superiors and subordinates (Su and Baird, 2018; Adi and Sukmawati, 2020).

Metrics for financial and non-financial performance measurement systems have been tested with a combination of levers of control as practiced by Ghozali and Sulityani (2016). These findings can influence psychological empowerment (Marginson et al., 2014) to improve organizational performance and increase the creativity of subordinates (Adi and Sukmawati, 2020), and improve the performance of subordinates in the subordinate work-related attitudes dimension. This is because levers of control can provide an essential framework for the consequences of performance measures (Franco-Santos et al., 2012; Marginson et al., 2014).

The combination of financial and nonfinancial performance measurements with levers of control has been carried out by Afrizal et al. (2020) and Hernando (2020) which shows the diversity of results in the combination towards subordinate workrelated attitudes. The variety of findings is indicated because of the merging of two dimensions in one mediation Therefore, in this study only one dimension in one mediation, namely levers of control (Adi and Sukmawati, 2020).

Based on the previous studies, the current researchers are trying to research one public sector, namely the health sector Badan Layanan Umum Daerah (BLUD) Pusat Kesehatan Masyarakat (Puskesmas) or Regional Public Service Agency of Community Health Centre (hereafter, the term BLUD Puskesmas will be used throughout the article). Research on performance in the health sector is mainly carried out at hospitals. There are still few who do it at the Puskesmas, especially at that already has the label/status of BLUD or Regional Public Service Agency - considering that all Puskesmas will become BLUDs (Adam et al., 2017; Mawarni and Wuryani, 2020) because they are given flexibility in the form of the freedom to implement health business practices to improve services to the community in order to endorse the general welfare and to educate the nation's life (www.blud.co.id).

In order to improve professionalism and optimize health services, Puskesmas that have not implemented BLUD are required to implement BLUD. It is recognized that the implementation of BLUD in the regions still has various challenges. First, BLUD is still a new thing for local governments. As a result, local governments find it difficult to change the mindset of BLUD financial management which is considered the same as the usual local government financial management. In addition, the implementation of BLUD is still not considered a priority. Second, there are internal and external problems within the BLUD, namely the limited human resources who understand BLUD operations. Then, the dynamics of changing local government officials (internal and external BLUDs) led to different understandings of the BLUD flexibility policy. "So the management of BLUD is not optimal."

Puskesmas, is a facility provision of health services, the first level that has a vital role as a gatekeeper for people who want to get referral health services (Shidiq et al., 2018). Permendagri or the Regulation of the 
Minister of Domestic Affairs No. 792018 about BLUDs or Regional Public Service Agency explains that government organizations implementing BLUD financial management are obliged to measure performance, including financial and service, and improve its performance. Permendagri or the Regulation of the Minister of Domestic Affairs No. 792018 about BLUDs or Regional Public Service Agency also show that administrative required for BLUD: (1) Letter of ability to improve performance, (2) Corporate Governance mechanisme, (3) Stategical Planning, (4) Minimum Service Standard, (5) Financial Statement, and (6) Last Audit Statement.

Government Regulation No. 122019 is stated that BLUD must be guided and supervised. Local governments can form BLUDs in the context of: improve services to the community according to with the provisions of the legislation. In order to improve services to community as referred to in paragraph (1), the Head of Regions set BLUD flexibility policies in Perkada implemented by BLUD management officials. The BLUD management officer as referred to in paragraph (2) responsible for policy implementation BLUD flexibility in providing service activities general, especially in the aspects of benefits and services generated.

This is reinforced by the Permendagri or the Regulation of the Minister of Domestic Affairs No. 77 2020. Therefore, guidance is carried out in facilitation, consulting, education and training, and research and development. In contrast, supervision is carried out in the form of audits, reviews, evaluations, monitoring, technical guidance, and other forms of supervision following the provisions of the legislation (Permendagri No. 77 2020).

Certainly, this becomes interesting in one of the provinces in Indonesia, which is Jambi province. Only two districts have started opening BLUDs for Puskesmas, namely Tanjung Jabung Barat district and Batanghari district. In Tanjung Jabung Barat district has 16 Puskesmas and Batanghari district has 18 Puskesmas. These Puskesmas have had some difficulties adapting to the BLUD changes where they are demanded to serve the community with excellence but must be independent and flexible in managing finances. The big question is "Can the BLUD Puskesmas improve performance after the status changes to BLUD? The performance that will be the focus of this research is the performance of BLUD employees consisting of the Head of the Puskesmas, Treasurer, Secretary and other Puskesmas employees, such as doctors, nurses, midwives, and others who become one unit, namely the BLUD Puskesmas.

There are four things that need to be considered by the regional government, including strengthening the role of regional governments in developing BLUDs, preparing regulations in the context of implementing BLUD management, increasing the capacity of human resources for managers, coaches, and supervisors of BLUDs, and budget allocations in the APBD as support for BLUD management.

Problems arise when the BLUD staff or employees are required to report their performance. They must prepare financial reports following the government accountting standards and the statements of Permendagri or the Regulation of the Minister of Domestic Affairs No. 77 2020. This becomes weird to the staff of the BLUD Puskesmas because they have a health education background, but they must compile and report the financial statements of the BLUD Puskesmas. The Head of the Puskesmas and the district health office leadership ranks must strive for these staff to improve their performance. Among them are involving these staff in accounting training and applying a combination of financial and nonfinancial performance measures. This combination of financial and non-financial performance measures is the focus of this research because it is considered capable of influencing the performance of the BLUD Puskesmas employee, as has been done by 
several previous studies (Speklé and Verbeeten, 2014; Lau, 2015; Shahwan, 2015; Galant and Cadez, 2017; Susiana et al., 2018). The problems above become the underlying reasons for the researcher to determine the impact of combined non-financial and financial performance measures on the performance of BLUD Puskesmas employyees. Furthermore, the researcher also aims to find out whether the performance of BLUD Puskesmas employees can be mediated by the use of levers of control.

\section{LITERATURE REVIEW \\ Performance}

The scope of management accounting should focus on providing information that allows managers to evaluate subordinates. Subordinates tend to prefer the performance evaluation process (Hernando et al., 2020).

To find out the performance level achieved, a company needs to be assessed using performance measurement. There is a number of performance measures that companies use to evaluate the performance of their business units and the performance of their managers. This performance measure allows managers to stay focused on achieving company goals.

Performance measurement is different for each company depending on the scope of the business it runs. Performance results from the quality and quantity of the jobs achieved by an employee carrying out tasks assigned to him. So, it can be concluded that performance is an effort made and the results obtained by a person or group of people following their responsibilities to achieve company goals.

The use of a variety of performance measurements can change the behavior of superiors and subordinates who will have an impact on the performance of the company. Use of non-financial performance measurement is a complement to the previous performance measurement, namely the measureement of financial performance. Because some recent research states that the use of financial performance measurement is no longer relevant again for use in the company because it has several weaknesses in the concept of or methods and measurements and have not been able to provide reasons related to the relationship between superiors and subordinates (Hernando et al., 2020).

\section{BLUD}

Public sector organizations must provide good services to the community because they have a primary function in providing services to the public (Siska et al., 2021). One of the public sector organizations is a health organization, such as a hospital or Puskesmas that provides essential government-owned health services (Mawarni and Wuryani, 2020). Peraturan Menteri No 75 of 2014 concerning Puskesmas states that these community health centers must serve patients with good quality. This is an attempt to achieve the highest degree of public health. BLUD allows Puskesmas to use nontax state income (PNPB), namely income from patient services directly, without having to first be deposited into the state treasury (Sabardiman et al., 2020). This mechanism is undoubtedly beneficial for Puskesmas in providing medicines, paying for operational costs, and other expenses in the budget (Sabardiman et al., 2020). Without this flexibility, it seems complicated for Puskesmas to be able to provide excellent service in this era of BPJS or Health Social Security Administering Agency, because patients do not pay directly but use the capitation system; the sum of monthly payment paid ahead of time by Health BPJS to Health Facilities First Level based on the number of registered participants without considering the type and number and health services provided (PMK No 69 of 2013).

The change of the Puskesmas to become a regional business service agency is solely to be able to set an example concrete salient features of the implementation of resultsbased financial management (performance). There is no decision from the local government, especially regarding service rates (still using the old rate) after the establishment of 
the BLUD, making it difficult for the Puskesmas to plan the budget performance based. Support from various parties is needed for the continued success of based services performance through the BLUD Puskesmas to be efficient and effective in the future (Sabardiman et al., 2020).

Puskesmas that have become BLU/BLUD use minimum service standards that are determined by the minister/head of institution/governor/regent / mayor in accordance with their authority, must consider service quality, service equity and equality, cost and convenience to get service. In the case of Puskesmas, the minimum service standard is set by regional head with regional head regulations

Based on Permendagri or the Regulation of the Minister of Domestic Affairs No. 79 2018 about BLUDs or Regional Public Service Agency show that the next Regional Public Service Agency abbreviated BLUD is a system implemented by the technical implementters of regional offices/agencies in providing services to people who have flexibility in the pattern of financial management as exceptions to the provisions of regional management on generally. Flexibility in management patterns finance by implementing sound business practices to improve services to the community without looking for profit in order to advance general welfare and intellectual life nation. Healthy Business Practice is the implementation of functions organization based on the principles of management that both in the context of providing quality services, sustainable and competitive. Strategic Plan is a BLUD planning document for period 5 (five) years.

BLUD aims to provide public services more effectively, efficiently, economically, transparently and responsible with due observance of the principles of justice, appropriateness and benefit in line with Business Practices Healthy, to help achieve goals regional government whose management is carried out based on the authority delegated by the head area. BLUD is a regional wealth that is not separated from local government. BLUD is part of financial management area.

BLUD human resources consist of: (1) Management officer; and (2) Employee.

The Management Officer as intended is responsible for general performance operational, implementation of Flexibility policy and BLUD finance in service delivery. Whereas, the employee as intended organize activities to support performance BLUD. Appointment as intended according to the needs of professionalism, ability financial and based on the principle of efficiency, economical and productive in improving services.

The leader as intended has the following duties: (1) To lead, direct, develop, supervise, controlling, and evaluating the implementtation of BLUD activities to be more efficient and productive, (2) Formulate the determination of BLUD technical policies and other obligations in accordance with the policies that have been determined by the regional head, (3) Draw up strategic plan, (4) Prepare RBA, (5) Propose candidates for finance officers and officials technical to the regional head in accordance with the provisions, (6) Appoint other officials as needed; BLUD other than officials who have been appointed by laws and regulations, (7) Coordinate the implementation of BLUD policies that carried out by financial officers and technical officials, controlling the duties of internal control, as well as deliver and account for performance operational and financial BLUD to the head area; and (8) Other tasks assigned by the regional head according to their authority.

The BLUD supervisors consist of: a. Technical advisor and financial advisor; $b$. Internal control unit; and c. Supervisory Board.

Corporate Governance mechanism in the BLUD includes: (1) Institutions, (2) Work procedures, (3) Grouping of functions, and (4) Management of human resources.

Meanwhile, the preparation of the strategic plan in the BLUD contains: (1) 
Service development plans, (2) Strategic and policy directions, (3) Program and activity plans and (4) Financial plans.

Minimum service standards contains a minimum limit understand the types and quality of basic services: what should fulfilled by the Technical Implementation Unit of the Service/Agency Regions that will implement BLUD. Minimum service standards is regulated by a Regional Head Regulation for ensure the availability, affordability, equity, equality, convenience and quality of public services given by the Technical Implementation Unit of the Service/Agency Regions that will implement BLUD in accordance with the provisions of the legislation.

BLUD budget structure, consisting of: BLUD income; BLUD shopping; and BLUD financing. For BLUD income sourced from: services provided to society, bound grants and unbound grants obtained from the community or other bodies, current account service; interest income; advantage of the difference in the exchange rate of the rupiah against the currency foreign money; commissions, discounts or other forms as a result of from the sale and or procurement of goods and or services by BLUD; investment; and business development.

BLUDs can invest as long as they provide benefits for increasing income and increasing service to the community and does not interfere BLUD financial liquidity with due regard spending plans. The shortterm investment referred to is an investment that can be immediately liquidated and intended to be held for 12 (twelve months or less). Short-term investment as referred to can be done by optimizing the surplus shortterm cash with regard to the plan expenditure. Include: a. deposits in commercial banks with a term of 3 (three) up to 12 (twelve) months and/or which can be extended automatically: and b. short-term government securities.

On the other hand, the BLUD financial report consists of: (1) Budget realization statements, (2) Changes in budget balances over statements, (3) Balance sheet statements, (4) Operational statements, (5) Cash flow statements, (6) Owner equity statements, and (7) Notes to financial statements.

That is very hard to understand with health workers alumni. Health discipline background very burnout when face of financial statements. The Puskesmas financial statements is a report prepared by the management as follows: form of submission of an entity's financial statements. The financial statements is a submission information to parties with an interest in the entity, so that the content of the report local government health service finances must follow the provisions for financial reporting as regulated according to SAK, namely as a non-profit organization (PSAK No. 45) and undertakes to for the financial statements are audited by an independent auditor. Service financial statements health must be audited by an independent auditor (IAI, 2015).

\section{Reliance on Multiple Performance Measures}

There are several specific issues related to individual behavior in management accounting, that is performance measurement (Afrizal et al., 2020; Hernando, 2020). Performance measurement is crucial because it can provide reasons related to issues, phenomena, and problems in the current management accounting environment (Hartmann et al., 2010). Moreover, performance measurement is the primary key in implementing strategic plans, motivating subordinates with rewards and penalties, translating strategies into behavior, communicating wishes, providing feedback, monitoring progress, and evaluating the achievement of company goals (Abernethy et al., 2010; Sholihin, 2013; Hinkin and Schriesheim, 2015). This is in line with Speklé and Verbeeten (2014) that state performance measurement provides an opportunity to communicate clear objectives, evaluate the approach to goals and policies that are assumed to revise the policies implemented within the company. 
Empirical findings from several researchers (Hartmann et al., 2010) show that performance measurement can motivate and influence subordinates to achieve the goals desired by each manager to create maximum results that are in line with organizational goals. However, there are problems in the literature on reliance on accounting performance measures (from now on abbreviated as RAPM) because it has many weaknesses in concepts and measurements, research methods, and theory development (Hartmann et al., 2010). The RAPM literature has not provided a decent explanation of the concept of evaluative style and its correlation to subordinate behavior (Noeverman and Koene, 2012). The single construct in the RAPM literature was criticized by Hartmann et al. (2010) because of its inconsistent findings. Based on the findings of previous research, it is suggested that companies can take into consideratio increasing the diversity of performance measurements to encompass both financial and non-financial measures or RMPM.

Reliance on Multiple Performance Measures (RMPM) is a diversity of performance measurements, both financial and non-financial. The implementation of performance measurement exploration can improve performance. The adoption of both financial and non-financial performance measures is used to asseess performance because subordinates are more likely to agree when superiors use both performance measures.

Performance measures in this study focused on RMPM. The combination financial and non financial more affordable on performance.

\section{Levers of Control}

This study uses levers of control proposed by Simons (1994). Levers of control refers to a management control system consisting of four control systems, namely; belief system, boundary system, diagnostic control system, and interactive control system (Ghozali and Sulityani, 2016; Speklé et al., 2017; Bandiyono and Augustine, 2019; Adi and Sukmawati, 2020; de Haan-Hoek et al., 2020). In simple terms, Bandiyono and Augustine (2019) describe the four systems as follows. Belief system is a control system related to organizational values. Boundary systems are employee boundaries regarding what they cannot do. A diagnostic control system refers to a system that motivates employees to achieve goals and monitors performance mechanisms. Finally, the interactive control system is a two-way communication process between superiors and subordinates.

The levers of control framework consists of four system controls that work simultaneously to benefit the organization (Bandiyono and Augustine, 2019). Meanwhile, according to Tessier and Otley (2012) revealed that levers of control have positive and negative strengths. Where, two dimensions (belief system and interactive control system) are defined as positive levers of control. Meanwhile, the other two dimensions of levers of control, namely the boundary system and the diagnostic control system, are defined as negative levers of control. Levers of control are needed to direct the behavior of all employees in an effort to facilitate organizational learning in order to improve employee knowledge and skills at any time, the impact of which can improve organizational performance (Bandiyono and Augustine, 2019). Through these four dimensions of levers of control, the learning process in the organization will run well and will improve the abilities and competencies of employees which have an impact on improving organizational performance (Bandiyono and Augustine, 2019). It can be concluded that belief systems, boundary systems, diagnostic control systems and interactive control systems have a significant effect on organizational learning. In addition, there is a significant influence between organizational learning and organizational performance (Bandiyono and Augustine, 2019). 
The four levers of control systems complement each other. However, this research only focuses on two levers of control systems: the diagnostic control system and the interactive control system (Syofyan et al 2021). This is because diagnostic control systems in measuring performance are expected to increase the clarity of objectives, and interactive control systems are a positive force in organizations and complement diagnostic control systems. Both systems provide an essential framework for understanding the results of performance measures (Franco-Santos et al., 2012).

\section{RMPM and Performance}

Human resources have an essential role in determining the success of an organization because all the potential of human resources is very influential on the its efforts to attain its goals. To make changes in an organization, it requires human resources with good performance (Hernando, 2020). This performance can certainly increase if superiors can manage and use management tools to control and motivate their subordinates. RMPM is a strategy that superiors can use to better the performance of their subordinates. This is true to the findings from (Carlson et al., 2009; Ghozali and Sulityani, 2016; Galant and Cadez, 2017; Baird and Su, 2018).

RMPM uses a financial performance measurement system and a non-financial performance measurement system (Lau and Roopnarain, 2014; Susiana et al., 2018; Syofyan et al. 2021). It is supported by Permendagri No 79 of 2018 concerning BLUDs explaining that government organizations that implement BLUD financial management are required to measure performance, including financial and service performance, and improve their performance. It is hoped that implementing a financial performance measurement system and a non-financial performance measurement system are able to improve the performance of BLUD Puskesmas employees.
In line with Syofyan et al. (2021) combining performance measurement systems and levers of control can improve employee performance. Therefore, it will have an impact on the services provided and the satisfaction received by patients. Hence, the first hypothesis of this research is as stated below:

$\mathrm{H}_{1}$ : RMPM impacts the performance of employees

\section{RMPM, Diagnostic Control Systems and Performance}

The diagnostic use consists of the evaluation of critical performance variables (i.e., factors enabling the attainment of intended strategy) to monitor and coordinate the implementation of intended strategies. Diagnostic control systems in measuring performance can reduce the role ambiguity because diagnostic control systems can identify deviations that occur in the planning process and are indispensable when discussing company strategy. So, this study tries to combine financial measurement with a diagnostic control system. It is also supported by the findings (Hartmann et al., 2010) that financial measurement can influence evaluation fairness as a mediating variable even though only in consideration of leadership relationship to evaluation fairness.

This study uses a diagnostic control system as mediation in the relationship between RMPM and the performance of BLUD Puskesmas employees. The aims and objectives involve the diagnostic control system mediating variable because the findings of previous research are expected to mediate the RMPM relationship and performance. Thus, the hypothesis in this study is:

$\mathrm{H}_{2}$ : Diagnostic control system mediates the relationship between RMPM and performance of employees 


\section{RMPM, Interactive Control Systems and Performance}

The success of an organization reflects the performance of its superiors and subordinates. The measures used to assess the performance of superiors and subordinates so far have only relied on financial and non-financial performance (Galant and Cadez, 2017). Previous research findings prove that financial and nonfinancial performance are able to be combined with the levers of control to increase the performance of superiors and subordinates in the company (Marginson et al., 2014).

The combination of performance measurement with the levers of control is expected to avoid a decline in company performance caused by a decrease in the performance of superiors and subordinates (Su and Baird, 2018; Adi and Sukmawati, 2020). Interactive control systems are a beneficial force in organizations and complement diagnostic control systems, and both systems provide an essential framework for understanding the effects of performance measures (Franco-Santos et al., 2012). Based on the findings of previous research, the third hypothesis of this research is stated below.

$\mathrm{H}_{3}$ : Interactive control system mediates the relationship between RMPM and performance of employees

\section{RESEARCH METHOD}

This type of research uses a quantitative approach by collecting data to test research hypotheses. This study examines both the direct and indirect impacts of RMPM. Direct testing was carried out on the relationship of the influence of RMPM on the performance of BLUD Puskesmas employees. Meanwhile, indirect testing was carried out on the relationship between the influence of RMPM on the performance of BLUD Puskesmas employees mediated by levers of control (both on the diagnostic control system and the interactive control system).
The type of data used in this study is primary data which is obtained directly by researchers' first hand, namely the respondents in this study. Respondents were given a statement or question and asked for perceptions of the variables to be used. In contrast, the data source of this research is the primary data source acquired from the respondents' answers to the distributed questionnaires.

In collecting data, this study used surveys in the form of questionnaires. The research questionnaires were distributed using a hand delivery system technique. The questionnaires were submitted at the BLUD training conducted by the Indonesian Institute of Accountants (IAI) to BLUD Puskesmas employees. The purpose of using this hand delivery system technique is to create an emotional bond with the respondent. Thus, it has an impact on minimizing the low response rate on the questionnaires they fill out.

The instrument design of this study using previous questionnaire from (Hartmann et al. 2010; Lau, 2015; Marginson et al. 2014 and Sholihin et al., 2010). To build good questionnaire, author invited academician from accounting, business, economics and psychology also practitioner from human resources development. The questionnaire using ex-ante and ex-post methods. Consist of: minimize the double barrier question, minimize the typo, clear statements, to the point question or statements, interesting questionnaire, longwinded question or solid question and there are token or kit questionnaire.

The population of this study was employee of the BLUD Puskesmas in Batanghari District and West Tanjung Jabung District, Jambi Province. Meanwhile, a purposive sampling technique was used where the selected respondents had to comply with predetermined criteria. The criteria for selecting the sample include educational background, work experience, length of work, training, and workshops attended. The sample size follows the 
guidelines set by Hair et al. (2010), which is ten times the most significant formative indicators or ten times the number of the most extensive structural path. Based on the model from this study, there are five structural paths, so the minimum sample in this study based on Hair et al. (2010) is 50 respondents.

Meanwhile, the determination of the sample can also use the Cohen (1992) approach. Cohen (1992) approach in determining the number of samples considers statistical power and effect size. The structural paths in this study are five which means that if you want a significance level of $1 \%$ with a minimum $\mathrm{R}$ square of 0.50 , you must have a minimum number of samples of 62. This is not much different from the criteria for meeting the sample according to Hair et al. (2010) which was determined to be as many as 50 samples.

\section{Variable Operational Definition}

The dependent variable of this research is the employee performance of BLUD Puskesmas. The questionnaire used is a modification of the previous research questionnaire (Sholihin et al., 2010; Lau, 2015). Employee performance in this study uses eight-question indicator items with a Likert scale of 1-5.

The independent variable of this research is RMPM which consists of financial performance and non-financial performance measurements. This RMPM variable uses 12 indicators consisting of financial performance that uses a questionnaire Hartmann et al. (2010) with nine indicators on a Likert scale of 1-5, and non-financial performance also uses a questionnaire Hartmann et al. (2010) with three questions on a Likert scale 1-5.

The mediating variable in this study is levers of control. However, only two control systems were used in this study, namely, diagnostic control system and interactive control system. The questionnaire used is a modification of Marginson et al. (2014), where the diagnostic control system uses four-question indicators with a Likert scale of 1-5. Meanwhile, the interactive control system uses seven-question indicators with a Likert scale of 1-5.

This research uses a structural equation modeling - partial least square (SEM-PLS) analysis tool in testing the research hypothesis. The SEM-PLS software used in this research is Warp-PLS 7.0. Researchers frequently use SEM-PLS because of its benefits in testing the structure of the model. This multivariate analysis technique has an exploratory nature of research and has two constructs, namely formative and reflective (Hair et al., 2010). The reason of using SEMPLS multivariate analysis is to maximize the $r$-squared value of the criterion variable, which can be explained by predictive variables and can minimize the error value.

Validity testing can be divided into two tests, namely, convergent validity testing and discriminant validity testing (Hernando, 2020). The rule of thumb for convergent validity is when scores (values) from different instruments are then measured in the same construct having a high correlation (Hernando, 2020). There are several criteria in determining convergent validity, including the fact that the value of outer loading must be higher than 0.7 (> 0.7). The value of communality must be higher than 0.5 (> 0,5), and the average variance extracted (AVE) value must be higher than 0.5 (> 0.5). On the other hand, the rule of thumb of discriminant validity testing is obtained when the scores (values) of different instruments are then measured in uncorrelated constructs resulting in uncorrelated scores (values). The rule of thumb for discriminant validity testing in this research uses the root square of AVE, which must be greater than the correlation of latent variables. It can also use cross-loading, which must be greater than $0.7(>0.7)$ in one variable.

This reliability test is needed to find out how consistent the results of the measurement of the construct or research concept are. The rule of thumb reliability test 
can use Cronbach's alpha where the value of Cronbach's alpha must be greater than 0.7 (> 0.7). In addition to Cronbach's alpha value, the following rule of thumb is related to reliability testing, namely composite reliability, with the composite reliability value having to be greater than 0.7 (> 0.7).

\section{ANALYSIS AND DISCUSSIONS}

This study employs a structural equation modeling-partial least square (SEM-PLS) analysis tool in testing the research hypothesis. The research questionnaires were distributed to all BLUD Puskesmas in Tanjung Jabung Barat District and Batanghari District, Jambi Province. A total of 81 questionnaires were successfully collected and passed the purposive sampling stage, and passed the validity and reliability tests.

Validity testing in this study was tested on two, namely, convergent validity and discriminant validity. The results of the convergent validity test can be met if they meet the following conditions: factor loading parameters with a rule of thumbs must be more than 0.7 . Then, the average variance extracted (AVE) parameter with the rule of thumbs must be more than 0.5. Furthermore, the communality parameter with the rule of thumbs must be more than 0.5. While the discriminant validity test can be met if it meets the following requirements; AVE root parameters and the correlation of latent variables with the rule of thumbs AVE roots $>$ the correlation of latent variables or AVE roots must be greater than the correlation of latent variables. Finally, the cross-loading parameter with the rule of thumbs must be more than 0.7 in one variable.
The results of the convergent and discriminant validity testing in this study were by the rule of thumbs. The loading and cross-loading factors have a value of more than 0.7 , and the average variance extracted, and communality has a value of more than 0.5 . Thus, the data in this study have passed the tests of convergent validity and discriminant validity. Furthermore, reliability testing is carried out to assess the internal consistency of the measuring instrument. Reliability testing uses two methods, which are Cronbach's alpha and composite reliability. The rule of thumb from Cronbach's alpha and Composite reliability is that it must be more than 0.7 even though the value of 0.6 is still accepted. The reliability test results in this study also showed that the data had met the reliability test. The results of reliability testing is displayed in Table 1 as follows:

Table 1 above shows that the value of Cronbach's alpha on the RMPM, diagnostic, interactive, and performance variables are $0.760,0.882,0.808$, and 0.873 respectively, this means that all variables have met the requirements with the parameter Cronbach's alpha with a rule of thumbs must be higher than 0.7. Meanwhile, the composite reliability parameter with the condition of the rule of thumbs 0.7 is also fulfilled. Each variable has a composite reliability value on the RMPM, diagnostic, interactive, and performance variables worth of 0.840, 0.919, 0.860 , and 0.901 . The two requirements above indicate that this research data has also passed the reliability test with Cronbach's alpha and composite reliability parameters.

Table 1

Cronbach's alpha and Composite Reliability

\begin{tabular}{lcccc}
\hline \hline & RMPM & Diagnostic & Interactive & Performance \\
\hline Cronbach's alpha & 0.760 & 0.882 & 0.808 & 0.873 \\
Composite reliability & 0.840 & 0.919 & 0.860 & 0.901 \\
\hline
\end{tabular}

Sources: Processed Data (2021) 


\section{Hypotheses Testing}

Hypothesis testing in this research examines the relationship between direct and indirect effects between variables. The direct affect in this study hypothesizes the reliance on multiple performance measures (RMPM) on the performance of BLUD Puskesmas employees. The results of the direct effect test in this study do not support the first hypothesis with a coefficient value of $0.160(p<0.07)$ and R2 is 0.77 (Table 2). This means that the first hypothesis in this research is not supported significantly.

The next test is the indirect effect. This study uses two indirect effects, namely a diagnostic control system and an interactive control system that mediates the relationship between the influence of RMPM on the performance of BLUD Puskesmas employees in the districts of Tanjung Jabung Barat and Batanghari Jambi Province. The results of testing the indirect influence hypothesis in this study are shown in the following results of the warp pls output (Table 3).

Based on the results of the WarpPls output as shown in the picture above (Picture 1), the diagnostic control system can mediate the relationship between the influence of RMPM on the performance of the BLUD Public Health Center employees. The RMPM coefficient path to the Diagnostic control system is 0.55 with a significance $(<0.01)$. Then, the diagnostic control system path coefficient to performance decreased to 0.53 with a significance of $(<0.01)$. This indicates that the second hypothesis in this research is supported by the form of mediation, namely partial mediation.

Table 2

Direct Effect

\begin{tabular}{ccccc}
\hline \hline Path & Path Coefficient & P Values & R-Squared & Results \\
\hline RMPM - Performance & 0.160 & $<0.07$ & 0.77 & Not Supported \\
\hline Sources: Processed Data (2021) & & & &
\end{tabular}

Table 3

Indirect Effect

\begin{tabular}{|c|c|c|c|c|}
\hline Path & $\begin{array}{r}\text { Path Coefficier } \\
\text { Square }\end{array}$ & and $\mathrm{R}-$ & Mediation & Results \\
\hline $\begin{array}{l}\text { RMPM - Diagnostic - } \\
\text { Performance }\end{array}$ & $0.55^{*}$ and 0.30 & $0.53^{*}$ & $\begin{array}{l}\text { Partial } \\
\text { Mediation }\end{array}$ & $\begin{array}{l}\text { Supported } \\
\text { Significant }\end{array}$ \\
\hline $\begin{array}{c}\text { RMPM - Interactive - } \\
\text { Performance }\end{array}$ & $0.47^{*}$ and 0.22 & $0.29 *$ & $\begin{array}{c}\text { Partial } \\
\text { Mediation }\end{array}$ & $\begin{array}{l}\text { Supported } \\
\text { Significant }\end{array}$ \\
\hline
\end{tabular}

Sources: Processed Data (2021)

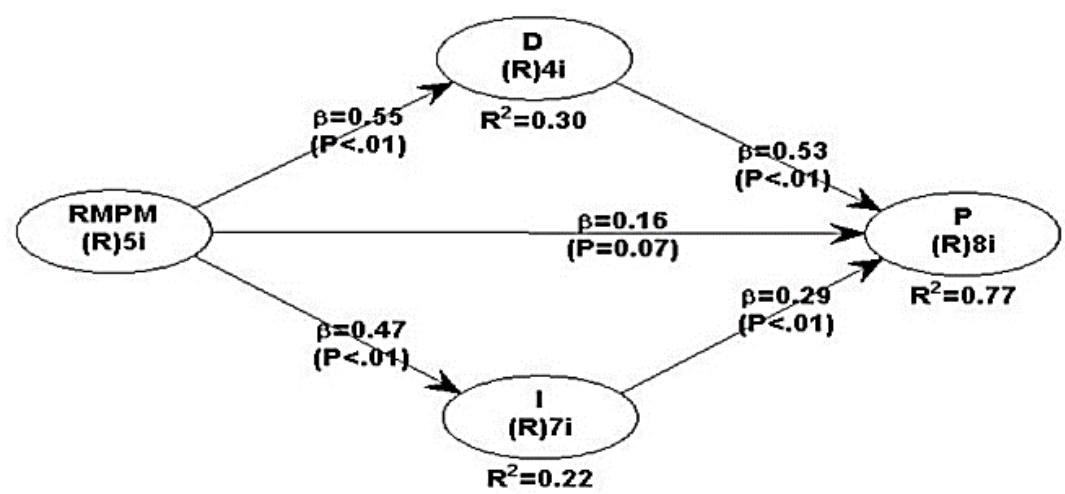

Picture 1

Output of Direct and Indirect Test Results 
Then, WarpPls output in the picture above shows that the interactive control system can mediate the relationship between the influence of RMPM on the performance of the BLUD Public Health Center employees. The RMPM coefficient path to the Interactive control system is 0.47 with a significance $(<0.01)$. Then, the interactive control system path coefficient to performance decreased to 0.29 with a significance of $(<0.01)$. This indicates that the third hypothesis in this research is supported by the form of mediation, namely partial mediation.

Of the three hypotheses proposed in this study, one hypothesis is not supported, namely the relationship between the influence of RMPM on the performance of BLUD Puskesmas employees. The findings in this study are not in agreement with previous research. Chow and Stede (2006) found that companies using financial and non-financial measures had higher financial, operations, employee empowerment, and customer aspects. The results of this research are also not in compliance with the findings obtained by Speklé and Verbeeten (2014) stating that various performance measurements can improve performance; similar to those obtained by Sholihin et al. (2010). Overall, the findings in this study contradict those of previous research. However, the output of Warp-pls shows that 77\% (R2 = 0.77) of the performance of BLUD Puskesmas employees is influenced by other variables dominantly, one of which is levers of control. In this case, the two levers of control variables that are used as mediation in this study are supported and significant even though they only partially mediate.

The indirect effect test showed different results from the direct effect test in this study because the results showed support for the second and third hypotheses in this study. Of course, this result is in accordance with the findings obtained by Marginson et al. (2014) saying that performance can be optimized if the performance measurement system also involves some dimensions of levers of control, namely diagnostic control system and interactive control system. These results also support other finding from (Sholihin et al., 2010), even though it only affects performace directly without being mediated by the levers of control.

According to the work manual for the Puskesmas, the District/City and Provincial Health Offices routinely set targets or standards of success for each program activity. Implementation standards This program is also an employee performance standard. Performance standards is a qualitative measure and is measured by comparing the targets that have been set with the output (coverage of services) program activities. Qualitatively, the success of the program is measured by compare standard work procedures for each program activity with appearance (ability) of staff in carrying out the activities of each program. Program coverage can be analyzed directly by puskesmas staff by analyzing daily data for each program activity. Changes in people's knowledge, attitudes and behavior (effect program) and program impact (impact) programs) such as mortality, morbidity (including malnutrition), birth rates, and disability not directly measured by the Puskesmas.

\section{CONCLUSION AND SUGGESSION}

The findings of this study shows that the leaders of the BLUD Puskesmas must implement a variety of performance measurements accompanied by the implementation of levers of control both in the utilization of the diagnostic control system and interactive control system. The reason is because implementing a variety of measurements alone can not affect the performance of BLUD employees, the Head of the Puskesmas as the leader must also apply the two levers of control. It is expected that applying a variety of performance measurements and levers of control can increase employee performance, which impacts the level of satisfaction of services provided by the Puskesmas to the 
community. A high level of community satisfaction with the services provided by the Puskesmas will increase public trust in the Puskesmas itself. Furthermore, this has an impact on the success of government programs in terms of health services. Implementing the diagnostic control system and interactive control system will provoke or stimulate creative ideas from the employees in terms of providing opinions regarding the strategies carried out and the efficiency of expenditures or strategies in increasing the amount of income. This is because BLUD Puskesmas are given the flexibility to manage their finances. The independent nature of this Puskesmas can later be used as a role model for agencies with BLUD status in their environment.

The contribution of this research practice is expected to guide company leaders in general, to use accounting and nonaccounting performance measurement systems in influencing employee performance and using levers of control in these relationships to improve performance so that it has an impact on the sustainability of the company. Specifically, in the BLUD institution, this research contributes to the Head of the Puskesmas to motivate their subordinates to be creative and innovative in terms of increasing income and reducing expenses. Furthermore, it can also motivate them in actively finding the best strategy for the progress of the BLUD Puskesmas together without reducing the quality of health services provided to the community. The theoretical contribution of this research is expected to be a guide for further research by developing or innovating the model and construct of this research. Lastly, it can be used as a reference in improving the model for further research.

This research certainly has some limitations. Among them, concepts and theories regarding levers of control have never been tested in BLUD agencies. Therefore, the researchers are faced with a lack of scientific references to strengthen or confirm the findings of this research.
Additionally, this research has problems in terms of total respondents being cut in half due to the criteria set. As a result, it is possible that the results of these findings will be different if this study involved all respondents, namely employees of BLUD Puskesmas in Tanjung Jabung Barat District and Batanghari District, Jambi Province. Another limitation is the fact that Batanghari District has just applied the BLUD statute to Puskesmas in the Regency, so it takes time to adapt and adjust to the new rules that were not previously enforced. Lastly, the limitation of this research is in the questionnaire, which did not go through the pilot test.

\section{DAFTAR PUSTAKA}

Abernethy, M. A., J. Bouwens, and L. van Lent. 2010. Leadership and Control System Design. Management Accounting Research 21(1): 2-16.

Adam, E., A. Suparwati, and S. Arso. 2017. Analisis Kesiapan Implementasi Badan Layanan Umum Daerah Puskesmas Kota Semarang (Studi Kasus Pada Puskesmas Ngesrep Dan Bandarharjo). Jurnal Kesehatan Masyarakat (e-Journal) 5(1): 59-67.

Adi, M. and A. Sukmawati. 2020. The Effect of Levers of Control and Leadership Style on Creativity. Journal of Indonesian Economy and Business 35: 236-256.

Afrizal, R. Hernando, W. E. Putra, and Yuliusman. 2020. The Leadership Styles, Performance Measures, And Levers of Control on Subordinates Work Relatedattitudes: The Indonesian Case Study. PalArch's Journal of Archaeology of Egypt/Egyptology 17(6SE): 12617-12635.

Baird, K. and S. Su. 2018. The Association between Controls, Performance Measures and Performance. International Journal of Productivity and Performance Management 67(6): 967-984.

Bandiyono, A. and Y. Augustine. 2019. Organizational Performance as a Mediation on the Effect of Levers of. 
International Journal of Business, Economics and Law 19(5): 65-78.

Carlson, D. S., K. M. Kacmar, and L. L. Wadsworth. 2009. The Impact of Moral Intensity Dimensions on Ethical Decision-Making: Assessing the Relevance of Orientation. Journal of Managerial Issues 21(4): 534-551.

Chow, C. and W. Stede. 2006. The Use and Usefulness of Nonfinancial Performance Measures. Management Accounting Quarterly 7(3): 1-8.

Cohen, J. 1992. A Power Primer. Psychological Bulletin 112(1): 155-159.

de Haan-Hoek, J., W. Lambrechts, J. Semeijn, and M. C. J. Caniëls. 2020. Levers of Control for Supply Chain Sustainability: Control and Governance Mechanisms in a Cross-Boundary Setting. Sustainability 12(8): 3189.

Franco-Santos, M., L. Lucianetti, and M. Bourne. 2012. Contemporary Performance Measurement Systems: A Review of Their Consequences and a Framework for Research. Management Accounting Research 23(2): 79-119.

Galant, A. and S. Cadez. 2017. Corporate Social Responsibility and Financial Performance Relationship: a Review of Measurement Approaches. Economic Research-Ekonomska Istraživanja 30(1): 676-693.

Ghozali, I. and L. Sulityani. 2016. Firm Capabilities Role as Mediator Variable of Relationship Between Levers of Control and Firm Performance (Empirical Study on Financial Institution in Indonesia). International Journal on Information 19(7A): 2533-2553.

Hair, J. F., W. C. Black, B. J. Babin, and R. E. Anderson. 2010. Multivariate Data Analysis. Prentice Hall. Upper Saddle River.

Hartmann, F., D. Naranjo-Gil, and P. Perego. 2010. The Effects of Leadership Styles and Use of Performance Measures on Managerial Work-Related Attitudes. European Accounting Review, 19(2): 275310.
Hernando, R. 2020. Pengaruh Kepemimpinan Struktur Inisiasi, Objektif Diagnostik dan Objektif Interaktif Terhadap Kejelasan Tujuan. Jurnal Manajemen Dan Bisnis Sriwijaya 18: 113120.

Hernando, R., E. Prasetyo, and R. Abdurrahman. 2020. Pengaruh Gaya Kepemimpinan Struktur Inisiasi, Subjektif Diagnostik, Subjektif Interaktif terhadap Keadilan Evaluasi. Jurnal Kajian Manajemen Bisnis 9(2): 56-66.

Hinkin, T. R. and C. A. Schriesheim. 2015. Leader Reinforcement, Behavioral Integrity, and Subordinate Outcomes: a Social Exchange Approach. The Leadership Quarterly 26(6): 991-1004.

Ikatan Akuntan Indonesia. 2015. Pernyataan Standar Akuntansi Keuangan (PSAK) 45 tentang Pelaporan Keuangan Entitas Nirlaba.

Lau, C. M. 2015. The Effects of Nonfinancial Performance Measures on Role Clarity, Procedural Fairness and Managerial Performance. Pacific Accounting Review 27(2): 142-165.

Lau, C. M. and K. Roopnarain. 2014. The Effects of Nonfinancial and Financial Measures on Employee Motivation to Participate in Target Setting. The British Accounting Review 46(3): 228-247.

Marginson, D., L. McAulay, M. Roush, and T. van Zijl. 2014. Examining a Positive Psychological Role for Performance Measures. Management Accounting Research 25(1): 63-75.

Mawarni, E. A. and E. Wuryani. 2020. Analisis Kinerja Puskesmas Yang Menerapkan Pola Pengelolaan Keuangan Badan Layanan Umum Daerah (PPK-BLUD) (Studi pada Puskesmas Krian Kabupaten Sidoarjo). Jurnal Akuntansi AKUNESA 09(01).

Noeverman, J. and B. Koene. 2012. Effects of Managerial Evaluative Styles on Subordinate Attitudes and Performance: Proposals for Future Research. The International Journal of Management 29: 219-231. 
Peraturan Menteri Dalam Negeri Republik Indonesia Nomor 77 Tahun 2020 Tentang Pedoman Teknis Pengelolaan Keuangan Daerah.

Peraturan Menteri Kesehatan Republik Indonesia Nomor 69 Tahun 2013 tentang Standar Tarif Pelayanan Kesehatan Pada Fasilitas Kesehatan Tingkat Pertama dan Fasilitas Kesehatan Tingkat Lanjutan dalam Penyelenggaraan Program Jaminan Kesehatan.

Sabardiman, K., A. Afrizal, and N. Nurmaesah. 2020. Evaluasi Perubahan Puskesmas menjadi Badan Layanan Usaha Daerah (BLUD) Terhadap Tata Pengelolaan Keuangan Daerah. Jurnal Proaksi 7(2): 194-212.

Shahwan, T. M. 2015. The Effects of Corporate Governance on Financial Performance and Financial Distress: Evidence from Egypt. Corporate Governance 15(5): 641-662.

Shidiq, M. A., A. Sriatmi, and S. P. Arso. 2018. Analisis Budaya Organisasi Puskesmas Sebagai Badan Layanan Umum Daerah (Blud) Di Kota Semarang. Jurnal Kesehatan Masyarakat (Undip) 6(2):1-8.

Sholihin, M. 2013. How Does Procedural Fairness Affect Performance Evaluation System Satisfaction? (Evidence from a UK Police Force). Gadjah Mada International Journal of Business 15(3): 231-247.

Sholihin, M., R. Pike, and M. Mangena. 2010. Reliance on Multiple Performance Measures and Manager Performance. Journal of Applied Accounting Research 11(1): 24-42.

Simons, R. 1994. How New Top Managers Use Control Systems as Levers of
Strategic Renewal. Strategic Management Journal 15(3): 169-189.

Siska, M., R. N. Sari, and Y. M. Basri. 2021. Determinan Kinerja Sektor Publik: Dimoderasi Sistem Pengendalian Interen pada Puskesmas BLUD di Kota Pekanbaru. Jurnal Akuntansi Indonesia 10(1):81-95.

Speklé, R., H. Van Elten, and S. Widener. 2017. Creativity and Control: a Paradox. Evidence from the Levers of Control Framework. Behavioral Research in Accounting 29(2): 73-96.

Speklé, R. F. and F. H. M. Verbeeten. 2014. The Use of Performance Measurement Systems in the Public Sector: Effects on Performance. Management Accounting Research 25(2): 131-146.

Su, S. and K. Baird. 2018. The Role of Leaders in Generating Management Innovation. The International Journal of Human Resource Management 29(19): 2758-2779.

Susiana, S., Y. Yusnaini, M. Gaol, I. Ghozali, and F. Fuad. 2018. Comprehensive Performance Measurement System, Procedural Fairness and Managerial Performance. Journal of Business and Retail Management Research 12(4): 117125.

Syofyan, E., R. Hernando, and D. Septiari. 2021. The Role of Leadership Style, Financial and Non-Financial Performance, Levers of Control on Evaluation Fairness. AKRUAL: Jurnal Akuntansi 13(1): 94-108.

Tessier, S. and D. Otley. 2012. A Conceptual Development of Simons' Levers of Control Framework. Management Accounting Research 23(3): 171-185.

www.blud.co.id. Pendampingan Online melalui BLUD.co.id. 